УДК 351.74: 342.922

DOI https://doi.org/10.32837/pyuv.v2i3(28).357

Ю. В. Срмаков

orcid.org/0000-0333-1677-4437

здобувач кафедри адміністративного та митного права

Університету митної справи та фінансів

\title{
ДЕРЖАВНА МІГРАЦІЙНА СЛУЖБА УКРАЇНИ ЯК ОСНОВНИЙ СУБ'ЄКТ ЗДІЙСНЕННЯ АДМІНІСТРАТИВНӦ̈ ПРОЦЕДУРИ У СФЕРІ МІГРАЦІЇ
}

Центральний орган виконавчої влади - це Державна міграційна служба України (далі - ДМС). У своєму функціонуванні ДМС спрямовується й координується Кабміном України через Міністра внутрішніх справ. Функціональні повноваження ДМС детально викладені в Положенні про Державну міграційну службу України. Аналіз цього нормативно-правового акта дозволяє зазначити, що у сфері громадянства ДМС відповідно до покладених на неї завдань ухвалює рішення про встановлення належності до громадянства України, оформлення набуття громадянства України, скасування таких рішень, безпосередньо здійснюе провадження 3 питань прийняття до громадянства України та про припинення громадянства України, надсилає відповідні документи на розгляд Комісії при Президентові України з питань громадянства, а також забезпечує виконання рішень Президента України з питань громадянства, оформлює та видає громадянам України документи, що посвідчують особу та підтверджують громадянство, тобто паспорти, а також у передбачених законодавством випадках тимчасово затримує та вилучає такі документи. У галузі імміграції ДМС приймає рішення про видачу дозволу на імміграцію, відмову в його видачі та скасування такого дозволу, здійснює оформлення і видачу документів для тимчасового або постійного проживання в Україні. У галузі еміграції ДМС оформлює і видає документи для виїзду за межі України тощо [21]. Зазначений обсяг компетенцій дозволяє визнати ДМС України основним суб'єктом публічного адміністрування в галузі реалізації адміністративних процедур у сфері міграції.

Історія існування ДМС не налічує ще й десяти років. Цей орган був створений у 2011 р. Указом Президента України від 6 квітня 2011 р. № $405 / 2011$, яким був визначений правовий статус ДМС як центрального органу виконавчої влади [11]. До цього моменту питання реєстраційного оформлення громадянства та міграційних процесів перебували у компетенції спеціального структурного органу МВС України - Державного департаменту громадянства, імміграції та реєстрації фізичних осіб, головним завданням якого у досліджуваній сфері було підтримання правопорядку та запобігання злочинності. Метою цієї структур- ної трансформації було створення органу не правоохоронної, а публічно-сервісної функціональної спрямованості. Сьогодні органами ДМС надається широкий арсенал адміністративних послуг, зокрема: у сфері громадянства відбувається оформлення та видача паспорта громадянина України, набуття громадянства України, прийняття до громадянства України, поновлення у громадянстві України, оформлення та видача довідки про реєстрацію особи громадянином України тощо; у сфері імміграції - оформлення дозволу на імміграцію та посвідки на постійне проживання іноземцям та особам без громадянства; у сфері еміграції - оформлення документів для виїзду громадян України за кордон на постійне проживання [1].

Зазначене дає підстави для висновку, що адміністративні процедури у сфері міграції являють собою моделі адміністративних проваджень 3 надання публічних послуг, які є окремим різновидом адміністративно-процедурної діяльності $[9$, с. 43]. 3 огляду на це цілком логічним вважаємо припущення, що для аналізу ефективності адміністративно-процедурного забезпечення досліджуваної сфери слід звернутися до розгляду практичної діяльності ДМС в аспекті надання вищенаведених адміністративних послуг.

Значне підг'рунтя для такої аналітичної роботи створене сумісною працею правозахисної організації «Асоціація українських моніторів дотримання прав людини в діяльності правоохоронних органів» та науковців Харківського інституту соціальних досліджень [1]. На підставі результатів дослідження багатьох джерел (зокрема, громадської думки стосовно діяльності міграційної служби, відображеної у відгуках на інтернет-форумах, а також даних судової практики, аналізу матеріалів у 3MI) автори дійшли висновку щодо незадовільного стану надання адміністративних послуг у сфеpi міграції, здійснюваного ДМС. Серед основних проблем, що роблять публічно-сервісну діяльність ДМС невідповідною до суспільних запитів, названо недосконалий порядок надання послуг (інакше кажучи, непрозорість і ускладненість адміністративних процедур), неузгодженість питання щодо платності зазначених послуг, корумпованість та зловживання владою з боку працівників підрозділів ДМС [1, с. 12]. 
Розглянемо зазначені пункти детальніше та спробуємо встановити, чи не змінилася ситуація в бік нормалізації після проведення цитованого дослідження. По-перше, стосовно недовершеності процедур, які визначають порядок надання послуг, маємо зазначити існування багатьох спроб вдосконалити нормативно-правову базу, призначену для регламентування процедур надання публічних послуг як взагалі, так і у сфері громадянства та міграції зокрема. Якщо на 2013 р., як стверджують автори цитованого дослідження, ситуація відрізнялася нерегулярністю, хаотичністю та неузгодженістю змін нормативно-правової бази, призначеної для регулювання організації здійснення адміністративних процедур територіальними підрозділами ДМС [1, с. 12], то сьогодні можна констатувати наявність позитивних змін. Так, лише протягом останніх трьох років удосконалення адміністративно-процедурного забезпечення надання публічних послуг в досліджуваній галузі відбувалося за рахунок конкретизації та уточнення документів, що використовуються для оформлення адміністративних послуг, внесенням змін до Класифікатора продукції та документів, що використовуються для оформлення адміністративних послуг $[19 ; 22 ; 14 ; 15]$.

Якщо досконалість і простота процедури надання послуг у досліджуваній сфері досі перебуває у процесі становлення, то проблему непрозорості, окремо виділену авторами дослідження якості надання ДМС публічних послуг як функціональний недолік [1, с. 12], наразі можна вважати вирішеною. Відповідно до положень Закону України «Про доступ до публічної інформації» [17], що став гарантією забезпечення прозорості системи публічного управління, ДМС на власному офіційному сайті пропонує потенційним замовникам адміністративних послуг повну інформацію щодо порядку і строків їх надання, підстав та умов для відмови в їх наданні, необхідного переліку потрібних для отримання послуги документів, а також щодо вартості конкретної послуги [3], тобто стосовно усіх процедурних аспектів адміністративно-сервісного провадження. $\mathrm{У}$ такий спосіб нівелюються можливості зловживання владними повноваженнями у вигляді затягування строків і витребування зайвих документів для отримання послуги, які ускладнювали публічно-сервісну діяльність підрозділів ДМС ще п'ять років тому.

Також вважаємо, що втратила актуальність така проблема досліджуваної сфери в аспекті платності конкретних послуг, як непрозоре ціноутворення. Відповідно до вимог постанови Кабміну України «Деякі питання надання адміністративних послуг у сфері міграції [6] ДМС був затверджений Класифікатор адміністративних послуг із обов'язковим зазначенням вартості конкретної послуги в національній валюті, який протягом часу свого існування неодноразово піддавався змінам $[14 ; 16 ; 15]$. Чинний сьогодні Класифікатор був затверджений Наказом ДМС від 29 січня 2018 p. № 18 [15]. Якщо раніше в нормативних актах одночасно використовувались терміни «вартість адміністративної послуги», "розмір адміністративного збору», «гранична вартість», через що встановити кінцеву суму оплати пересічному громадянину було не так вже й просто, то нині на офіційному сайті ДМС пропонуються детальні роз'яснення щодо цієї термінології. Зокрема, стосовно послуги отримання закордонного паспорта наводиться тлумачення адміністративного збору, який слід оплатити, як суми вартості адміністративної послуги та вартості бланка документа: 253 грн - вартість послуги, 304 грн 32 коп. - вартість бланку, загалом (адміністративний збір) 557 грн 32 коп. [4].

Дещо складніше охарактеризувати стан речей стосовно наявності корупційних проявів та зловживання владними повноваженнями в адміністративно-сервісній діяльності ДМС України. На думку представника Української Гельсінської спілки 3 прав людини О. Левицького, діяльність ДМС супроводжується низкою системних порушень прав людини. Це зумовлено наявністю в зазначеного органу виконавчої влади дискреційних повноважень, завдяки яким «хочемо - даємо (дозволи, статуси, посвідки, громадянство), хочемо - назад забираємо" [8]. Деякі рішення ДМС, що набули особливо гучного суспільного розголосу завдяки 3MI, взагалі дозволяють запідозрити наявність певних політичних механізмів у використанні зазначених дискреційних повноважень підрозділами міграційної служби. Маємо на увазі, зокрема, справу інструктора-волонтера Національної гвардії грузинського походження М. Абашидзе, якому замість надання громадянства України Управлінням Державної міграційної служби у Луганській області було таємно, без повідомлення скасовано посвідку на постійне проживання та відмовлено в її продовженні, на підставі чого 11 листопада 2017 р. правоохоронними органами М. Абашидзе було видворено з України [13]. Зазначимо, що ці рішення адміністративного органу були оскаржені до Луганського окружного адміністративного суду, який 21 травня 2018 р. виніс рішення про їх незаконність та скасування [12].

На нашу думку, такі прогалини в діяльності органів виконавчої влади свідчать саме про недосконалість адміністративно-процедурного забезпечення надання публічних послуг у сфері громадянства та міграції, адже саме чітке закріплення й точне дотримання моделі відносин між суб'єктами публічної влади та фізичними особами забезпечує реалізацію суб'єктами владних повноважень своїх компетенцій виключно в межах закону. 
Ще один проблемний момент у діяльності органів та підрозділів ДМС пов'язаний із делегуванням функцій щодо надання адміністративних послуг у сфері міграції Державному підприємству «Документ». Створене у 2003 році, воно виступає адміністратором Єдиного державного демографічного реєстру. Основною метою його діяльності $є$ «впровадження нових сервісів і стандартів надання послуг, створення сучасних умов для обслуговування громадян України, іноземців та осіб без громадянства» [12].

Однак серед вітчизняних адміністративістів та правозахисників функціонування цього державного підприємства оцінюється 3 дещо інших позицій. Так, В.П. Тимощук відверто називає «Документ» «корупційною прокладкою між міграційною службою та українцями» [23] та «легалізованою паразитуючою структурою» [10]. Автори цитованого вище аналітичного дослідження адміністративних послуг, що надаються ДМС та MBC, зазначають, що у свідомості громадян діяльність цього підприємства часто небезпідставно асоціюється з такими явищами, як здирництво, корупція та державний рекет [1, с. 16].

Загалом функції зазначеного підприємства дублюють функції підрозділів ДМС, при цьому оплата за однакові послуги в «Документі» дещо вища, ніж в управліннях міграційної служби. Здавалося б, нічого особливого: звичайна конкуренція, споживачі публічних послуг можуть вільно обрати, який сервіс та за які гроші вони хочуть отримати. Однак, як справедливо стверджує В.П. Тимощук, ні про яку чесну конкуренцію у сфері публічних послуг у даному разі навіть і не йдеться. Для конкурентного стану в цьому секторі послуг має бути вжитий принцип єдиної ціни [23]. Така ситуація загрожує тим, що в підрозділах ДМС штучно створюються черги, порушуються строки розгляду поданих одержувачем послуги документів, свідомо робляться максимально незручні умови, чим стимулюються звернення споживачів саме до державного підприємства "Документ», гроші з рахунків якого використати набагато простіше, аніж з бюджету, куди потрапляють гроші за оплату наданих ДМС послуг [21]. У такий спосіб надання публічних послуг державною установою за сприяння посадових осіб перетворюється на бізнес-проєкт.

У справі паспортизації населення підприємство «Документ» становить конкуренцію не лише територіальним управлінням ДМС, а й центрам надання адміністративних послуг (далі - ЦНАП). ЦНАП - це постійно діючий робочий орган або структурний підрозділ місцевої держадміністрації або виконавчого органу місцевої ради. Такі робочі органи, як і територіальні управління ДМС, являють собою регіональний рівень здійснення адміністративних процедур у досліджуваній сфе- pi. У галузі громадянства та міграції на ЦНАП (на відміну від підрозділів міграційної служби) покладається обмежений обсяг компетенцій, пов'язаний із оформленням та видачею паспорта громадянина України, реєстрацією місця проживання особи, оформленням, видачею та обміном паспорта громадянина України для виїзду за кордон. Головна мета існування ЦНАП полягає у децентралізації діяльності щодо адміністративних послуг, що закріплено Розпорядженням КМУ № 523 від 16.05.2014 р. "Деякі питання надання адміністративних послуг органів виконавчої влади через центри надання адміністративних послуг» [6].

Згідно $з$ положеннями зазначеного Розпорядження надання послуг, що стосуються галузі громадянства та міграції, здійснюється суб'єктами, передбаченими Законом України «Про Єдиний державний демографічний реєстр та документи, що підтверджують громадянство України, посвідчують особу чи їі спеціальний статус», ст. 2 якого визначає такими суб'єктами розпорядника Реєстру - центральний орган виконавчої влади, що реалізує державну політику у вказаній сфері, тобто ДМС, а також центри надання адміністративних послуг і державне підприємство, що належить до сфери управління розпорядника Реєстру міграції, тобто «Документ» [18]. Було б логічно, якщо б у світлі сучасного тяжіння адміністративної діяльності до децентралізації зазначені функції були б остаточно передані до ЦНАП, але цього не відбулося. Відповідь, вважаємо, полягає в тому, що децентралізація стосується не лише перерозподілу повноважень та відповідальності. Вагомий її аспект становить фінансовий складник. Можливість відтоку оплати за отримання затребуваних публічних послуг, пов'язаних із паспортизацією, у місцеві бюджети зовсім не надихає представників центральних органів виконавчої влади делегувати свої повноваження на місця. Так, станом на 1 березня 2018 року повноваження із надання паспортних послуг ЦНАП виконувались у 74 містах/селищах/селах у 23 областях (в т.ч. і у м. Київ). При цьому лише у 13 містах - обласних центрах (Києві, Вінниці, Луцьку, Дніпрі, ЖЖитомирі, Івано-Франківську, Львові, Одесі, Полтаві, Рівному, Сумах, Харкові, Чернігові) - паспортизація відбувалася через ЦНАП [24].

Таким чином, можна констатувати, що складається ситуація штучного затримання процесу децентралізації в публічно-сервісній галузі сфери міграції. На наше глибоке переконання, саме на ЦНАП мають покладатися повноваження в аспекті паспортного обслуговування населення. Коло компетенцій органів ДМС має бути зосереджене на наданні адміністративних послуг громадянам України, що виїжджають за кордон для постійного перебування, та іноземцям і особам 
без громадянства, що бажають мешкати в Україні. Такий розподіл повноважень дозволить кожному з названих органів сконцентрувати увагу на власній ділянці роботи відповідно до принципу предметної компетенції. Діяльність же державного підприємства «Документ» у цій галузі, на нашу думку, має бути припинена як потенційно корупціогенна.

Виявлено суттєвий структурно-функціональний недолік в аспекті паспортизації населення, що проявляється у фактичному дублюванні функцій територіальними управліннями ДМС України та ЦНАП. На нашу думку, усунення цього недоліку прямо пов'язане з чіткім розподілом компетенцій між зазначеними суб'єктами. Функції з поточного обліку населення та здійснення відповідних адміністративних процедур оформлення (заміни) паспортів мають бути закріплені за ЦНАП, а функції з міграційного обліку та реалізації відповідних адміністративних процедур за управліннями ДМС. Єдиним винятком мають стати лише процедури паспортизації громадян України, що мешкають на тимчасово непідконтрольних територіях. 3 огляду на актуальний стан речей цей аспект сьогодні прямо пов'язаний із питаннями національної безпеки, що виходять за межі компетенції місцевих органів публічної влади, тому паспортизація громадян України, що мешкають на тимчасово непідконтрольних територіях, має залишатися у віданні підрозділів центральних органів виконавчої влади, тобто управлінь ДМС.

Аналіз практичного аспекту функціонування зазначених суб'єктів дозволив виявити як позитивні зрушення, так і проблемні моменти в галузі адміністративно-процедурного забезпечення публічно-управлінської діяльності в досліджуваній сфері. Останніми роками були внесені значні корективи, що дозволили посилити прозорість реалізації адміністративних процедур та суттєво зменшити можливості розсуду суб'єктів публічного адміністрування стосовно встановлення вартості конкретних адміністративних послуг. Це можна вважати помітним кроком уперед у справі оптимізації адміністративно-процедурного аспекту. Однак залишаються актуальними питання вдосконалення нормативної бази процедурної діяльності адміністративних органів у цій сфері. Це стосується як становлення загальної правової основи у вигляді Адміністративно-процедурного кодексу або Закону «Про адміністративні процедури», так і деталізації окремих процедур, особливо тих, що регламентують відносини органів публічної влади зі специфічною групою громадян України - мешканцями тимчасово непідконтрольних територій. Означені напрями оптимізації слугуватимуть предметом аналізу в подальших розділах нашої дисертаційної роботи.

\section{Jimepamypa}

1. Адміністративні послуги ДМС та МВС: аналіз правових засад надання та результати соціологічного дослідження : науково-практичне видання / за заг. ред. Ю.Л. Бєлоусова, В.К. Батчаєва. Київ, 2013. 92 с.

2. Адміністративні послуги ДМС та МВС: аналіз правових засад надання та результати соціологічного дослідження. Науково-практичне видання / за заг. ред. Ю.Л. Бєлоусова, В.К. Батчаєва. Київ, 2013. 92 с.

3. Державна міграційна служба України : офіц. сайт. URL: https://dmsu.gov.ua/find.html.

4. Державна міграційна служба України : офіц. сайт. URL: https://dmsu.gov.ua/poslugi/dokumentidlya-vijzdu-za-kordon/vidacha-pasporta-gromadyaninaukrajni-dlya-vijzdu-za-kordon.html.

5. Державне підприємство «Документ». Державна міграційна служба України : офіц. сайт. URL: https://dmsu.gov.ua/pro-dms/struktura-ta-kontakti/ derzhavne-pidpriemstvo-dokument.html.

6. Деякі питання надання адміністративних послуг органів виконавчої влади через центри надання адміністративних послуг : Розпорядження КМУ № 523 від 16.05.2014 p. Офіційний вісник України. 2014 р. № 45. Стор. 208. Стаття 1193. Код акту 72712/2014.

7. Деякі питання надання адміністративних послуг у сфері міграції : Постанова Кабінету Міністрів України від 02.11.2016 № 770. URL: https://zakon.rada.gov.ua/ laws/show/770-2016-\% D0\% BF.

8. Завдяки юристам УГСПЛ особа без громадянства виграла суд у Державної міграційної служби. Українська Гельсінська спілка з прав людини : офіц. сайт. Новини від 30.08.2017 p. URL: https://helsinki.org.ua/articles/zavdyaky-yurystamuhspl-osoba-bez-hromadyanstva-vyhrala-sud-uderzhavnoji-mihratsijnoji-sluzhby/.

9. Легеза Є.О. Провадження з надання публічних послуг органами виконавчої влади. Науковий вісник Міжнародного гуманітарного ун-ту. Серія «Юриспрудениія». 2016. № 19. С. 42-44.

10. Пирожок О. «Готово!», «Документ» и другие: как государство зарабатывает на гражданах. Українська правда : офіц. сайт. 13 серпня 2018 р. URL: https://www.epravda.com.ua/rus/publications/2018/ 08/13/639430/.

11. Питання Державної міграційної служби України : Указ Президента України від 06.04.2011 p. № 405/211. URL: https://zakon.rada.gov.ua/laws/ show $/ 405 / 2011$.

12. Постанова Луганського окружного адміністративного суду у справі № 812/333/18 від 21.05.2018 р. Єдиний державний реєстр судових рішень. URL: http://reyestr.court.gov.ua/Review/74225642.

13. Права Людини в Україні. Інформаційний портал Харківської правозахисної групи. URL: http://khpg.org/index.php?id=1527841821.

14. Про внесення змін до Класифікатора адміністративних послуг, що надаються територіальними органами та підрозділами ДМС, Класифікатора продукції і документів, що використовуються для оформлення адміністративних послуг, Класифікатора адміністративного збору, що включає вартість адміністративної послуги, вартість бланка документа та його персоналізацію : Наказ ДМС України від 13.12.2016 p. № 328. Державна міграційна служба України : офіц. сайт URL: https://dmsu.gov.ua/ assets/files/doc/n328\% 20.pdf.

15. Про внесення змін до Наказу ДМС від 03.11.2016 р. № 280 «Про затвердження класифікаторів адміністративних послуг, продукції і документів, що використовуються для оформлення адміністратив- 
них послуг, адміністративного збору, що включає вартість адміністративної послуги, вартість бланка документа та його персоналізацію» : Наказ ДМС України від 29.01.2018 р. № 18. Державна міграційна служба України : офіц. сайт. URL: https://dmsu.gov.ua/assets/ files/doc/n 2018 18.pdf.

16. Про врегулювання питання сплати адміністративних послуг : Наказ ДМС України від 02.06.2017 p. № 140. Державна міграційна служба України : офіц. сайт. URL: https://dmsu.gov.ua/assets/files/doc/ n140\% 10.pdf.

17. Про доступ до публічної інформації : Закон України від 13 січня 2011 року № 2939-VI. Відолості Верховної Ради України (ВВР). 2011. № 32. Ст. 314.

18. Про Єдиний державний демографічний реєстр та документи, що підтверджують громадянство України, посвідчують особу чи її спеціальний статус : Закон України № 5492-VI від 20.11.2012 р. URL: https:// zakon.rada.gov.ua/laws/show/5492-17.

19. Про затвердження класифікаторів адміністративних послуг, продукції і документів, що використовуються для оформлення адміністративних послуг, адміністративного збору, що включає вартість адміністративної послуги, вартість бланка документа та його персоналізацію : Наказ ДМС України від 03.11.2016 р. № 280. Державна міграційна служба України : офіц. сайт. URL: https://dmsu.gov.ua/assets/files/doc/ n280\% 20.pdf.

20. Про затвердження Положення про Державну міграційну службу України : Постанова Кабінету Міністрів України від 20.08.2014 р. № 360 . URL: https://zakon3.rada.gov.ua/laws/show/360-2014$\% \mathrm{D} 0 \% \mathrm{BF}$

21. Про затвердження порядку зарахування до бюджетів плати за надання адміністративних послуг та продукцію i документи, що використовуються для оформлення цих послуг : Наказ МВС України та Мінфіну України від 27.03.2017 р. № 259/390. URL: https://zakon.rada.gov.ua/laws/show/z0524-17.

22. Про затвердження типових інформаційних карток і зразків технологічних карток адміністративних послуг ДМС України : Наказ ДМС України від 28.12.2016 р. № 355. Державна міграційна служба України : офіц. сайт. URL: https://dmsu.gov.ua/assets/ files/doc/n 2016 355.zip.

23. Тимощук В. Громадяни продовжуватимуть сплачувати ДП «Документ» сотні мільйонів гривень щорічно за послуги, які чиновники мають надавати безоплатно. Деловая столииа: новостной ежене дельник. URL: http://www.dsnews.ua/society/viktortimosh chuk-gromadyani-prodovzhuvatimut splachuvati-26012016093200.

24. Як запровадити видачу у ЦНАП біометричних паспортів? ЦНАП: Портал реформи адміністративних послуг. URL: http://cnap.in.ua/passport-in-cnap/.

\section{Анотація}

Срлаков Ю. В. Державна міграційна служба України як основний суб'єкт здійснення адміністративної процедури у сфері міграції. - Стаття.

Наукова стаття присвячена характеристиці повноважень Державної міграційної служби України як основного суб'єкта здійснення адміністративної процедури у сфері міграції.

Доведено, що на ЦНАП мають покладатися повноваження в аспекті паспортного обслуговування населення. Коло компетенцій органів ДМС має бути зосереджене на наданні адміністративних послуг громадянам України, що виїжджають за кордон для постійного перебування, та іноземцям і особам без громадянства, що ба- жають мешкати в Україні. Такий розподіл повноважень дозволить кожному з названих органів сконцентрувати увагу на власній ділянці роботи відповідно до принципу предметної компетенції. Діяльність же державного підприємства «Документ» у цій галузі, на нашу думку, має бути припинена як потенційно корупціогенна.

Виявлено суттєвий структурно-функціональний недолік в аспекті паспортизації населення, що проявляється у фактичному дублюванні функцій територіальними управліннями ДМС України та ЦНАП. Усунення цього недоліку прямо пов'язане з чіткім розподілом компетенцій між зазначеними суб'єктами. Функції з поточного обліку населення та здійснення відповідних адміністративних процедур оформлення (заміни) паспортів мають бути закріплені за ЦНАП, а функції з міграційного обліку та реалізації відповідних адміністративних процедур - за управліннями ДМС. Єдиним винятком мають стати лише процедури паспортизації громадян України, що мешкають на тимчасово непідконтрольних територіях. 3 огляду на актуальний стан речей цей аспект сьогодні прямо пов'язаний із питаннями національної безпеки, що виходять за межі компетенції місцевих органів публічної влади, тому паспортизація громадян України, що мешкають на тимчасово непідконтрольних територіях, має залишатися у віданні підрозділів центральних органів виконавчої влади, тобто управлінь ДМС.

Ключові слова: адміністративна процедура, державна міграційна служба, міграція, суб’єкти.

\section{Summary}

Yermakov Yu. V. The State Migration Service of Ukraine as the main subject of administrative procedure in the field of migration. - Article.

The scientific article is devoted to characterizing the powers of the State Migration Service of Ukraine as the main subject of administrative procedure in the sphere of migration.

It is proved that the CNAP should be empowered in the aspect of passport servicing of the population. The scope of competence of the LCA should be focused on providing administrative services to citizens of Ukraine traveling abroad for permanent residence and to foreigners and stateless persons who wish to reside in Ukraine. Such a distribution of powers will allow each of these authorities to concentrate their attention on their own site of work in accordance with the principle of substantive competence. In our opinion, the activity of the state-owned enterprise "Document" in this area should be terminated as potentially corrupt.

A significant structural and functional defect was revealed, which manifests itself in the actual duplication of functions by the territorial departments of the LCA of Ukraine and the CNAP in the aspect of population certification. The elimination of this deficiency is directly related to the clear division of competencies between the indicated entities: functions on current population registration and implementation of appropriate passport registration (replacement) procedures should be assigned to the CNAP, migration accounting functions and implementation of relevant administrative procedures - by departments LCA. The only exception should be the procedures for the certification of Ukrainian citizens residing in temporarily uncontrolled territories. Given the current state of affairs, this aspect is today directly linked to national security issues that fall outside the competence of local public authorities, so it should remain under the control of the units of central executive bodies, in our case - the LCA.

Key words: administrative procedure, state migration service, migration, subjects. 